\title{
Permanent professional education in healthcare services
}

\author{
Educação permanente nos serviços de saúde \\ Educación permanente en los servicios de salud
}

\author{
Kátia Ferreira Costa Campos ${ }^{1}$ \\ Roseni Rosângela de Sena ${ }^{1+}$ \\ Kênia Lara Silva ${ }^{1}$
}

1. Universidade Federal de Minas Gerais (NUPEPE/UFMG). Belo Horizonte, MG, Brazil. † In memoriam.
Corresponding author:

Kátia Ferreira Costa Campos.

E-mail: katiacostacamposenf@gmail.com

Submitted on 10/31/2016.

Accepted on 04/25/2017.

DOI: 10.1590/2177-9465-EAN-2016-0317

\begin{abstract}
Objective: To analyze the literature on permanent education, identifying the conceptual evolution and its application in health services in Brazil. Method: An integrative review of the literature was performed. A total of 54 studies written in English, Portuguese and Spanish, published from January 1970 to May 2016 from the databases of the Virtual Health Library, were included. Results: Conceptual problematization was highlighted as a contribution to educational actions, indicating a conceptual development of permanent education in Brazil. However, permanent education actions sometimes occur independently from the work process. There are difficulties in understanding and application, with repercussions for health services, revealing that professionals' and managers' commitment is a challenge. Implications for practice: Continuing education is a field that lacks investments for the transformation of reality in the health service routine in Brazil.
\end{abstract}

Keywords: Permanent education; Work process; Health services.

\section{Resumo}

Objetivo: Analisar a literatura sobre educação permanente, identificando a evolução conceitual e sua aplicação nos serviços de saúde no Brasil. Método: Revisão integrativa de literatura. Foram incluídas 54 publicações em inglês, português e espanhol, de janeiro de 1970 a maio de 2016, provenientes das bases da Biblioteca Virtual em Saúde. Resultados: Destacou-se a concepção problematizadora como aporte para as ações educativas, indicando avanço conceitual sobre a educação permanente no Brasil. No entanto, as ações de educação permanente, por vezes, acontecem desarticuladas do processo de trabalho. Existem dificuldades de compreensão e aplicação, com repercussões nos serviços de saúde, revelando-se como desafio o comprometimento dos profissionais e gestores. Implicações para a prática: A educação permanente é campo que carece de investimentos, visando à transformação da realidade no cotidiano dos serviços de saúde, no Brasil.

Palavras-chave: Educação Permanente; Processo de Trabalho; Serviços de Saúde.

\section{Resumen}

Objetivo: Analizar la literatura sobre la Educación Continua, identificando la evolución conceptual y su aplicación en los servicios de salud en Brasil. Método: Revisión integrativa de la literatura. Se incluyeron 54 estudios en inglés, portugués y español, desde enero de 1970 hasta mayo de 2016, a partir de las bases de la Biblioteca Virtual de Salud. Resultados: Se destacó la concepción problematizada como contribución a la educación, lo que indica avance conceptual en la educación continua en Brasil. Sin embargo, las acciones de educación permanente, por veces, suceden desconectadas del proceso de trabajo. Existen dificultades en la comprensión y aplicación, con repercusiones en los servicios de salud, revelándose como un reto el compromiso de los profesionales y directivos. Implicaciones para la práctica: La educación continua es un campo que necesita más inversión para la transformación de la realidad en la vida cotidiana de los servicios de salud en Brasil.

Palabras clave: Educación Continua; Proceso de Trabajo; Servicios de Salud. 


\section{INTRODUCTION}

The discussion on education as transformative practice and meaningful learning is essential for permanent education $(P E)$, as it represents an important field of knowledge and practice in the health area. This recognition, in its turn, has been constructed by education theoreticians based on the discussion about adult education, including the health sector as a permanent need for professional and worker qualification, aiming to achieve critical and reflective training to deal with reality and to transform it. ${ }^{1-3}$

The concept of education encompassing the construction of critical awareness and reflective reasoning for human development ${ }^{2,4}$ has guided discussions on permanent education in the health sector in Latin America and Brazil, guided the Pan American Health Organization (PAHO) in the 1970s, with a focus on the work process, appreciation of experiences and practices in health care for social subjects, aiming to redirect health education processes, in view of learning in the workplace. In this sense, the debates have advanced, triggering changes in the existing concepts of professional education. ${ }^{5}$

In Brazil, at the same time that there is development in the field of permanent health education influenced by the PAHO, the discussion about professional education in health gained space in the Health Reform. The "Conferências Nacionais de Saúde" (CNS - Brazilian Health Conferences) of 1986 and 1993 included the $1^{\text {st }}$ and $2^{\text {nd }}$ Brazilian Conferences on Human Resources for Health respectively, with records on the need for training aimed at reality. In this context, the idea that health professionals were essential for the required changes in the ways health care occurred was defended. 6,7

In 1996, the $10^{\text {th }}$ CNS was held, whose report suggested the creation of programs on permanent qualification and training, permanent education and motivation of health professionals and workers by the Ministry of Health and State and City Departments of Health. ${ }^{8}$ In this sense, in 2001, the Ministry of Health established the guidelines for the establishment of a national policy on health, confirming the responsibility of the SUS in the management of professional qualification in this sector. ${ }^{9}$ Thus, in 2003, the "Secretaria de Gestão do Trabalho e da Educação na Saúde" (SGTES - Department of Work and Health Education Management) was created as part of the Ministry of Health, with the purpose of promoting the formulation of policies on the qualification and development of health professionals and workers and directing the inclusion of the policy on permanent education in health services. ${ }^{10}$

The creation of the SGTES enabled a significant development in the field of professional health education. Moreover, in 2004, the Ministry of Health established the "Política Nacional de Educação Permanente em Saúde" (PNEPS - Brazilian Policy on Permanent Health Education), aiming to strengthen the "Sistema Único de Saúde" (SUS - Unified Health System). In this context, learning in the workplace, through work and for work was regarded as an assumption, based on the problems encountered in the reality of services. Permanent education in the health sector was subsequently adopted to enable a collective reflection on work and to provide an instrument for its transformation. ${ }^{11}$

With the publication of this policy, permanent education was emphasized in the development of professionals for the reality of services, with the implementation of three devices: permanent health education centers, training for permanent education facilitators and the network of supporting cities, aiming to establish an inter-institutional interaction between state and city managers, educational institutions, professors and students, social control health institutions and health care services. ${ }^{11}$

In 2007, Decree 1996 was issued, establishing the National Policy on Permanent health education, in addition to new guidelines and strategies for its implementation, considering the characteristics of each region and, mainly, the needs for training and development for health work. ${ }^{12}$ During this time, the concepts guiding permanent health education are expected to have changed in terms of definitions and their application to services. Thus, being aware of the conceptual contribution of permanent education is believed to be relevant, aiming to have a better understanding of current events.

As a result, the present study set out from the following guiding question: What is the development and conceptual contribution of permanent education and its application in health services in Brazil? Aiming to answer this question, the objective was to analyze the literature on permanent education, identifying the conceptual development and its application in health services in Brazil.

Thus, this study is justified when considering the fact that permanent education is of great importance to society and needs to be explored as a way to enable reflection on the reality of health services. It is important to understand that the transformation of the health care model in the Unified Health System can be enhanced through the incorporation of permanent education, as a device that enables self-analysis and changes in the health service routine. Thus, new ways to think and act should be encouraged, with the development of critical awareness and the reflection on possible innovative forms of producing health and organizing work processes, health services, professional training, management and social control.

In this sense, Paulo Freire's theoretical basis of dialogic learning guided this study as it showed the dimension of unfinished character of human beings and the reality of constant change. This includes the need for education as a constantly changing activity, based on the critical reading of reality for its own transformation.

\section{METHODS}

A qualitative, exploratory study on an integrative literature review was performed. This integrative review presupposes the previous preparation and validation of the study protocol, with the establishment of well-defined criteria for data collection, analysis and presentation of results. ${ }^{13}$ The following steps were taken: problem identification; literature review; critical assessment; data analysis; and presentations and interpretation of results. ${ }^{14}$ To 
achieve this, a review protocol was developed and publications were subsequently selected.

After the problem and question of this study were identified, the literature was reviewed, according to the following inclusion criteria: studies in English, Portuguese or Spanish; and publications between January 1970 and May 2016, the period between the beginning of the discussion on permanent education by the Pan American Health Organization (PAHO), in Latina America and Brazil, and the current year (2016). Moreover, qualitative and quantitative studies dealing with the object of this study that responded to the guiding question and met the study objective were also taken into consideration. The exclusion criteria defined were as follows: reports on experiences; analysis on permanent education; articles on theoretical reflection; project documents; literature review without an available abstract that did not deal with conceptual aspects; and application of permanent education in Brazil.

The following databases were selected for this study: "Literatura Latino-americana e do Caribe em Ciências da Saúde" (LILACS - Latin American and Caribbean Literature on Health Sciences), "Base de Dados Bibliográficos Especializada na Área de Enfermagem" (BDENF - Specialized Bibliographic Database on Nursing), Medical Literature Analysis and Retrieval System Online (MEDLINE) and Pan American Health Organization (PAHO). Descriptors and key words in Portuguese, English and Spanish were used, combined with each other. "Permanent education" and "Work process" were the key words and "health services" were the exact descriptor, with the combination (ti:(("educação permanente" OR "permanent education" OR "Educación permanente"))) AND (instance:"regional") AND (la:("pt" OR "es" OR "en" OR "pt-br") AND type:("article")).

The first search was performed in 2015, with a new survey in May 2016 and a review in January 2017. A total of 396 publications were found and, after selection based on the restrictions of language and databases, 355 were defined for title reading. During this stage, 60 titles were excluded due to reports of experience, literature review, titles indicating permanent education, and publications that did not deal with permanent education in Brazil, so that 295 studies remained. After these were verified and repetitions were excluded, 248 studies remained to be screened for abstracts.

Abstract reading excluded the following: 22 publications without available abstracts; 30 articles on theoretical reflection; eight dealing with permanent education; nine literature reviews; 19 reports on experience; and 41 repetitions that were not detected in the title reading, totaling 129 exclusions, so that 119 publications remained. Subsequently, the full article reading excluded the following 67 publications: six reports on experience; 17 repetitions in languages; two literature reviews; two project documents; nine that could not be recovered in other databases and 31 that did not respond to the guiding question and/or study objective.

Next, 53 publications were selected and, through reverse search, i.e. search for reading of articles already identified, one more was selected, totaling a sample of 54 publications, as shown in Table 1, all of which were analyzed in this study. The selection process met the Prisma model guidelines, which indicates the stages of identification of publications in the databases, screens for titles and abstracts with full article reading for eligibility, and includes those that will be a part of the sample. ${ }^{15}$

Based on the reading of articles selected, each publication was filed, seeking general characteristics regarding language, profession of the first author, place of publication, databases and method adopted in the studies, and the response to the study objective. The results consisted in the analysis of all publications comprising the sample identified, which were analyzed and treated in a qualitative way.

For the stage of analysis and discussion, the convergence of ideas between authors was taken into consideration, thus enabling the categorization of results and discussion: "Evidence of permanent education in health services: bringing concept and practice closer together"; "Difficulties in conceptual understanding and application to health services"; and "Permanent education in health services: context and application". This stage was directed by Freire's dialogical theory, through which it is understood that individuals are praxis beings, who need to emerge from the world, aiming to know and transform it with their work, in a process of action and reflection on the world. ${ }^{2}$ Regarding ethical aspects, the principles of authorship of publications included in this study were respected.

\section{RESULTS AND DISCUSSION}

In terms of the general characteristics of publications, 51 were written in Portuguese, one in English, and two in Spanish. The majority of those in Portuguese were influenced by the selection of articles in Portuguese, when duplicated into Spanish and English, not enabling us to affirm that the theme of Permanent education in Brazil is not sufficiently covered by the international literature.

Among the first authors, 32 were graduated in nursing, two in dentistry, six in medicine, one in education, one in psychology, one in physical education, one in nutrition, and one in policy analysis, in addition to two master's students, three doctoral students and three undergraduate nursing students. Therefore, nursing showed a relevant number of publications, enabling one to infer that nurses have been more interested in studying Permanent education in their practice.

Regarding the place of origin of authors, 51 are from federal universities, institutes or foundations in the Southeastern, Southern, Mid-Western and Northeastern regions of Brazil, one is from a state university, and one from a city department of health. In terms of databases, 44 were located in the LILACS, six in the BDENF, two in the MEDLINE, and two in the PAHO. Concerning the methods used, qualitative studies stood out, the majority of which were descriptive and exploratory, some including case studies, cartography and documental analysis. 
Table 1. Sample selected in chronological order

\begin{tabular}{|c|c|c|c|}
\hline Publication & Publication & Publication & Publication \\
\hline $\begin{array}{l}\text { Haddad Roschke, Davini } \\
(1987)^{5}\end{array}$ & Fortuna et al. $(2011)^{37}$ & Silva et al $(2013 b)^{40}$ & Santos et al $(2015)^{50}$ \\
\hline Ricaldoni; Sena $(2006)^{18}$ & Silva et al $(2011)^{38}$ & Silva et al (2013a) & Signor et al $(2015)^{56}$ \\
\hline Lavado et al. $(2007)^{47}$ & Mendonça; Nunes $(2011)^{57}$ & Nicoletto et al $(2013)^{64}$ & Machado et al $(2015)^{28}$ \\
\hline Monteiro et al. $(2007)^{59}$ & Tesser et al. $(2011)^{36}$ & $\begin{array}{l}\text { Silva, Leite, Hidelbrandt, } \\
\text { Pinno, }(2014)^{48}\end{array}$ & $\begin{array}{l}\text { Slomp, Feuerwerker, merhy } \\
(2015)^{30}\end{array}$ \\
\hline Paschoal et al. $2007^{31}$ & Silva; Peduzzi (2011) 38 & $\begin{array}{l}\text { Pereira. Barbosa, Vernasque } \\
(2014)^{23}\end{array}$ & $\begin{array}{l}\text { Rocha, Bevilacqua, Barletto } \\
(2015)^{49}\end{array}$ \\
\hline Feliciano et al. $(2008)^{41}$ & Barbosa et al $(2012)^{63}$ & Salum; Prado $(2014)^{24}$ & Machado et al $(2015)^{28}$ \\
\hline Marandola et al. $(2009)^{43}$ & Cardoso $(2012)^{35}$ & $\begin{array}{l}\text { Lima, Albuquerque, } \\
\text { Wenceslau }(2014)^{55}\end{array}$ & Mishima et al (2015) ${ }^{44}$ \\
\hline Nicoletto et al. $(2009)^{33}$ & Coriolano et al. $(2012)^{29}$ & Silva, Leite, Pino $(2014)^{19}$ & Sade, Perez $(2015)^{51}$ \\
\hline Peduzzi et al. $(2009)^{46}$ & Silva et al $(2012 c)^{54}$ & Cunha et al $(2014)^{42}$ & Moraes; Ditz $(2015)^{61}$ \\
\hline Pinto et al. $(2010)^{32}$ & Paulino et al (2012) & Pinto et al $(2014)^{32}$ & $\begin{array}{l}\text { Yamamoto, Machado, Silva } \\
(2015)^{27}\end{array}$ \\
\hline Balbino et al (2010) & Duarte et al $(2012)^{22}$ & $\begin{array}{l}\text { Queiroz, Silva, Oliveira al } \\
(2015)^{21}\end{array}$ & Koerich, Erdmann. $(2016)^{26}$ \\
\hline Montanha; Peduzzi (2010) & Silva et al $(2012 b)^{20}$ & Viana et al $(2015)^{25}$ & Lemos $(2016)^{62}$ \\
\hline Rossetto; Silva $(2010)^{16}$ & Silva et al (2012a) & Ricardi; Sousa $(2015)^{52}$ & \\
\hline Carvalho et al $(2011)^{34}$ & Leite et al $(2012)^{53}$ & Paim, Ilha, Backes $(2015)^{58}$ & \\
\hline
\end{tabular}

Source: designed by authors.

\section{Evidence of permanent education in health services: bringing concept and practice closer together}

In this category, publications on concepts of permanent education were gathered. ${ }^{16-39}$ Several publications described permanent education as connected to unsystematic, noncontinuous and technically-based moments, disconnected from the work process. ${ }^{16-20}$ In contrast, other publications showed it as a continuing process, applied to health services, recognizing that this condition enables significant learning through active methods and problematization of reality in reflective group discussions about concrete situations and work routine. Thus, these publications acknowledge the need to develop educational actions included in the work process. ${ }^{21-28}$

In certain publications, the success of permanent education was associated with experiences, such as the one developed with nursing professionals and community health agents, supported by problematizing education to identify expectations of qualification results. Thus, the increase in critical reflection on work can be perceived, apart from the professional/user interaction and theoretical/practical connection, in an evident concept of professional education. ${ }^{29,30}$ However, publications on the problematizing concept in health services stood out, guiding the educational actions during their planning, execution and assessment, indicating that the conceptual development of permanent education appears to be a trend in Brazil.
Furthermore, studies indicate that problematization promotes a critical reflection on reality and praxis as knowledge about action that determines the transformation of social structures..$^{18}$ Training programs using problematization could be identified and collaborated to the perception of the importance of committing to the opportunity of reflecting on health work routine. Additionally, the training of facilitators enabled a broadening of the perspective of work practice and potential of permanent education. ${ }^{31-33}$

This educational model, whose theoretical-practical relationship is reflective, considers work to be a key aspect for permanent education. For this purpose, seeking methodologies that enable the organization of individuals' thinking about the complex reality of health services is relevant in educational processes, as it promotes the understanding of reality., ${ }^{3,10,18}$ In this sense, the adaptability of permanent education to the reality of contexts, actions and health services contributes to the actionreflection-action. ${ }^{34,41}$ In the same line, the process of permanent education has contributed to the improvement of professional qualification and work process organization. ${ }^{29,30}$

Publications on facilitators' training process for permanent education meetings - spaces for group discussion foreseen by the Brazilian Policy on Permanent health education -, revealed that the expression "permanent education" included the following concepts: a movement that allows for work analysis; a strategy for health professional qualification in a constant process of 
subjectivity; and management strategy, in the sense that it enables management reorganization from work problematization in its real contexts. ${ }^{34-37}$

Permanent education meetings were integrated into the national policy as settings for group discussion in the health context. ${ }^{10}$ Several concepts came together and had an effect on the way professionals understood the educational process and their interaction with the health routine. ${ }^{33,37}$ This space of discussion enabled SUS workers to raise their awareness and there was also the possibility of reflecting on complexity and subjectivity, which must be included in health services. ${ }^{36,38,39}$

Thus, the need to deepen permanent education is relevant, including the routine of health services, as these meetings are a wealth of possibilities of transformation and this is where the individuals performing actions in this area are found. Additionally, the teaching-service relationship was deficient, indicating the need to value bringing academic knowledge and health services closer together as a starting point. In this partnership, the construction of spaces for praxis is expected, with the transformation of both health practices and the academic world in the teaching-learning process. ${ }^{39}$

The multi-professional residence was recommended as a strategy for the dissemination of permanent health education among health professionals, users, professors and students. ${ }^{39}$ However, difficulties in conceptual understanding were identified in the literature and application of permanent education, which we propose to deal with in the next section.

\section{Difficulties in conceptual understanding and application to health services}

Difficulties in understanding the concept of permanent education were identified in the publications included in this category, ${ }^{34-36,40-49}$ having repercussions in the application to health services. Furthermore, there were challenges for permanent education, in terms of the commitment to professionals and managers. Thus, the importance of inter-disciplinary actions is emphasized, as permanent education is a team action..$^{40,45}$

There were gaps and difficulties in the implementation of permanent education in cities with experiences that, in the majority of times, were not changes in the way reality was experienced. ${ }^{41-43}$ In addition, there were the difficulties of local managers, due to insufficient knowledge about permanent education concepts and the responsibilities involved with its execution. ${ }^{44,45}$

Publications showed that professionals and managers are confused or lack awareness about the definition of permanent education, as it is frequently used as a synonym of permanent education or "health education", hindering the process of changes in practices. ${ }^{43,45}$ The concept of continuing education (CE) is found in services, creating confusion regarding the concept of permanent education. Continuing education is understood as the process that includes educational activities after professional qualification and aimed at refreshing courses and acquisition of new information, including specific activities, pre-defined contents and traditional methods. ${ }^{10}$
Other studies emphasized that, even when the term "permanent education" was used, many practices were in fact "continuing education", maintaining the confusion about the definition and use of these terms when referring to educational processes in services. ${ }^{40,46,47}$ In this sense, there is a dilemma regarding the use of terms that influence the organization and functioning of educational processes in health services, at times affirming this to be permanent education, although with continuing education practices, and vice-versa.

Moreover, difficulties in understanding permanent education as a process of change from conceptual aspects to the view of educational action as restricted to technically-oriented, established formal moments through the introduction of new equipment or government programs. ${ }^{33,34,36-47}$

A study on the evaluation of educational actions involving health teams enabled researchers to confirm the existing confusion about the use of the terms: at times the theory is about permanent education, although the experience is about continuing education, at other times, it is the opposite. ${ }^{43}$ The author ${ }^{43}$ draws attention to the fact that these concepts are not opposing, but rather have different purposes. However, these purposes must be clear and agree with educational practices, including teaching-learning processes that enable changes in work orientation aimed at the identification of health problems. ${ }^{43}$ In this respect, the educational practices in the field of mental health stood out, enabling a process of construction of reflective thinking and leading to the perception of other senses and ways in routine production. ${ }^{48,18}$

A study conducted with professionals of the Family Health Strategy ${ }^{49}$ concluded that higher education professionals did not consider courses and training courses to be capable of producing transformations in their health service practices. This study ${ }^{49}$ showed that there are effects of educational actions on team activities, with some orientation towards community reality, although without consistently changing traditional practices.

Professionals' difficulty in recognizing the daily problems was emphasized as the basis for the exercise of permanent education, which is developed from the problems and needs found in health services. ${ }^{35}$ In this sense, one should consider the fact that educational actions can take reality as the object. However, reality must be understood so it can be transformed. To achieve this, theoretical input has to be used to broaden the critical perspective of professionals, workers and managers in health services. In this sense, permanent education takes shape, as required by individuals who are immersed in their routine and the complexity of their problems, demanding urgent changes in the ways health care is provided.

Another important aspect is the warning about education, which must enable transformation with understanding of the world. This is where the task and objectives of permanent education are found, as they can contribute to adults' awareness of how their needs can be converted into problems, thus facilitating solution with a critical look, surpassing the naïve awareness of reality, assuming positions that are more in agreement with the dynamics of life..$^{1,2}$ 
When the complexity of health problems is taken into consideration, changes that should begin in primary care are emphasized, with possibilities of reorientation of the health care model and health network integration. Consequently, permanent education is considered to be the strategy to achieve this and as such it should receive investments aimed at understanding and dealing with health problems and needs. ${ }^{33,45}$

\section{Permanent education in health services: context and application}

The context and application of permanent education in health services have been recorded in publications $12,18,24,26,27,31,34,36,39,42,45,46,48,50,51,53,54,56-63,64$ that dealt with the relationship between the educational process, health practices and aspects associated with management, planning and assessment of permanent education. The relationship between permanent education and management stood out, indicating the need for managers to show better understanding and commitment. Studies have revealed that the understanding of permanent education and the context in which it is approached is essential to guide decisions about programs and actions in health services.

The identification of the context, social and economic determinants, policies on education, work and social development are indicated as requirements for the educational process to respond to concrete needs, consequently enabling the learning objectives to be set. ${ }^{5}$ In this sense, a proposal of permanent education must be used in the process of self-analysis of work, which can give the opportunity to reshape practices, seeking to transform individuals committed to the construction and strengthening of the SUS. ${ }^{47}$

Thus, education must be regulated by strategic management, seeking to reflect on the context of work and the actual problems encountered in the process of planning and development of managerial competences..$^{50}$ There is the possibility of such competences being developed based on demands from real work situations, in agreement with the logic of permanent education. ${ }^{51}$

On any level of management, the health system must provide proposals of transformation of practices, based on the critical reflection on health work and experimentation with the understanding of reality including those who experience it. ${ }^{51}$ In this sense, the policy on permanent education expresses the recognition of the intrinsic connection between management and education as the key aspect for the development of politicalmanagerial and educational strategies, seeking to appreciate health practices. ${ }^{12}$

Additionally, researchers assessed the difficulties for the democratization of workplaces in the construction of co-responsibility and development beyond educational practices. These difficulties were characterized by predetermined courses to specific categories, in addition to the desire of permanence, process control and job taking, among others. ${ }^{36}$ On the contrary, demands and initiatives must start from the local level, including group participation, interaction, and the search for partnerships and resources aimed at this purpose..$^{29,52}$
Professionals recognize the importance of the space for inter-institutional interaction, including several participants and bringing quality to the process of definition of educational demands. ${ }^{42}$ As an example, there is the study in the city of Vitória, ES, where permanent education meetings, as a space for group discussion, were the foundation for the educational and humanizing policy implemented in 2005, functioning as devices in this city. ${ }^{32}$

A study performed with nurses in the Family Health Strategy ${ }^{24}$ emphasized the relevance of the consolidation of permanent health education for the work process of nurses and showed workers' perception of the importance of permanent education in quality of care, even in view of several difficulties. In another study, ${ }^{25}$ permanent education was found to promote changes to the work process, enable health professionals to have critical and reflective qualification, increase social participation, and bring management and local health issues closer together, thus representing an assessment practice as well. ${ }^{25}$ In this sense, permanent education initiatives such as the Director Plan workshops in Minas Gerais state, Southeastern Brazil, have the potential of transforming health practices and health care organization. ${ }^{53,54}$

However, the work of a manager as the one who enables the interaction of and facilitates processes is essential for health care qualification. Additionally, it is an important way to increase funding in a management model that seeks to integrate all participants involved in the discussion about contexts, aiming to define the educational demands associated with real routine problems in health services. Thus, permanent education is a tool of great importance for management, especially on the local level, and it can be promoted through institutional support, among other devices. ${ }^{37,55}$

For local managers, permanent education is a privileged instrument that increases the quality of analysis of reality and the construction of more democratic actions both for management and work relationships. ${ }^{36}$ The implementation of such processes depends on the commitment of the participants involved, management, teaching-service interaction and investment in permanent education. ${ }^{26,27,56,57}$

In a study conducted with nurses,${ }^{51}$ there was a dissociation between teaching and service, lack of professional commitment, difficulty in managing individuals and lack of physical and financial resources and those of support from hierarchical superiors for permanent education. ${ }^{51}$ Such facts have repercussions for work and health care quality, as the changes required for improvement depend on the process of permanent education. A study ${ }^{58}$ performed in an intensive care unit showed a slow and steady process, although with significant results when the work qualification and innovation were analyzed.

The search for innovation in permanent education must be constant and involve raising the interest of those having new learning experiences. Managers and other professionals are challenged to enable ways of thinking that promote the development of the reflective capacity of service workers. ${ }^{18}$ Thus, 
permanent education can be seen as the mediator of changes and the possibility of development for human beings to deal with the world and (re)interpret reality, which must be constant in permanent cycles.

It is important to consider the fact that assessment becomes inherent in the process when a permanent production of permanent education is established. ${ }^{35,41}$ Lack of assessment or its weaknesses are a vulnerable point for permanent education in the studies analyzed. Some of the publications indicate that the educational assessment has weaknesses in the stages of discussion of proposals, planning and execution. ${ }^{47,59}$

The decree issued by the Ministry of Health in 2007 and the booklet on permanent education of 2014 emphasize that the implementation, monitoring and assessment of public policies must consider learning aspects in a continuous process. In this respect, the importance of the following aspects stand out: the structuring of educational projects dependent on spaces and means for teams, users and educational institutions to actively participate; and the creation of planning, monitoring and assessment devices. ${ }^{12,60}$

More recent studies have revealed challenges for the "Política Nacional de Educação Permanente" (PNEPS - Brazilian Policy on Permanent education) in Brazil, such as the existence of a centralized management model on several levels and sectors. ${ }^{61-63}$ This includes a low level of participation of other civil society sectors, in addition to obstacles to funding, due to bureaucratic issues and loss of value of spaces for policies to be executed. For this reason, despite the persuasion of the PNEPS, it has not sufficiently contributed to the effective group construction of knowledge and transformation of the health care model, considering each reality and their unique constructions. ${ }^{61,62,64}$

Thus, the concept of permanent education in the PNEPS surpasses the educational meaning, as it seeks to respond to a process of restructuring of services, based on the new health care model demands. However, unlike a tool for transformation, permanent health education has exclusively been an educational novelty or an ideology that appeals to health services without actually transforming the SUS health care model. ${ }^{62}$ Thus, practices founded on new ways to operate the concept and application of permanent education in health services must be constructed.

\section{CONCLUSION}

The publications analyzed revealed a conceptual development in permanent education in Brazil. This development is characterized by the institutionalization of the health field from the 1970s onwards, with the Health Reform Movement and the construction of the SUS. Such concept was incorporated as an object of public policy in 2004, a strategy for the development of professional education in the health sector.

The concept of permanent education incorporated the principles of problematization, contextualization of reality, innovative educational methods, and reflective thinking. At the same time, it encountered difficulties regarding concepts and its application in the context of services. However, it is evident that permanent education has enabled gradual changes in the complex reality of health services. Additionally, the needs associated with management could be perceived. The centralized model of management hinders permanent education, indicating the need for investment in strategic management as a possibility for reflection and action when coping with real problems, especially on the local level of the health system.

In the perspective of Freire's Dialogical Theory, education should be capable of causing transformations in a relationship of praxis with reality. When transferring this concept to the health area in Brazil, the PNEPS brings the idea of learning in the workplace. However, conceptual difficulties are found to interfere with the reality of education of health professionals, including the appreciation of experiences of individuals who can become independent when dealing with the reality of health services and thus contribute to changes in the health care model.

In contrast, there were developments, such as problematization with positive results, in terms of the recognition of the need to transform reality. This perspective is approached both in the hospital area and primary care, the latter receiving more research funds.

It is evident that there are difficulties to associate the exercise of permanent education with the reality of health service routine in the work processes. Therefore, rethinking the group construction, democratization in the construction of co-responsibility, increase in the quality of analysis of reality, and learning development in the health service routine. To achieve this, one must overcome the fragmented education dissociated from reality, observing routine as a space full of possibilities to produce relevant learning and transformations in the health care model.

One of the implications for practice is that more investment should be made in permanent education in Brazil. It should not be limited to a tool for health system organization or a strategy for work process remodeling, including specific educational actions, restricted to established formal moments. Instead, it must be understood as a device used to mediate changes, enabling a process of self-analysis in the workplace, for work and beyond work, as a possibility of growth to cope with the world.

Some of the limitations of the present study were as follows: the search in three languages exclusively; the use of only one combination of key words and descriptors; and possible selection biases.

However, considering the categories resulting from this integrative review, we expect to have contributed to the debate on professional education in the health sector in a group process. This implies the creation of a new culture of development of health professionals and workers, in a dialogical concept. In conclusion, it is recommended that studies on practical experiences with permanent education in health care, management, teaching and social participation should be promoted, considering individuals in their health service routine. 


\section{ACKNOWLEDGEMENTS}

Thanks to FAPEMIG (Minas Gerais State Research Support Foundation) and CNPQ (National Council for Scientific and Technological Development) for funding the research project entitled "Permanent education in Health and ways to think and do management, health care, qualification and participation in and for SUS", from where the present study originated.

Thanks to the Pro-Rectory of Research of the Federal University of Minas Gerais (PRPq/UFMG).

\section{REFERENCES}

1. Furter P. Educação permanente e desenvolvimento cultural. Petrópolis: Vozes; 1974. 222 p.

2. Freire P.Conscientização - teoria e prática da libertação: uma introdução ao pensamento de Paulo Freire. São Paulo: Centauro; 2001. 102 p.

3. Haddad J, Roschke MAC, Davini MC. Proceso de trabajo y educacion permanente de personal de la salud: reorientacion y tendências em America Latina. Educ Med Salud. [Internet]. 1990; [cited 2017 Jan 8]; 24(2):136-204. Available from: http://www.scielo.br/scielo.php?script=sci_ nlinks\&ref=000206\&pid=S1981-7746201000020000300018\&lng=en

4. Bárcia MF. Educação permanente no Brasil. Petrópolis: Vozes; 1982. $88 \mathrm{p}$.

5. Haddad JQ, Mojica MJ, Chang MI. Proceso de educación permanente en salud. Educ Med Salud [Internet]. 1987;21(1):11-29. Available from: http://hist.library.paho.org/Spanish/EMS/938.pdf

6. Ministério da Saúde (BR). I Conferência Nacional de Recursos Humanos. Relatório final. Brasília: Ministério da Saúde; 1986. Available from: http://bvsms.saude.gov.br/bvs/publicacoes/0116conf_rh.pdf

7. Ministério da Saúde (BR). II Conferência Nacional de Recursos Humanos para a Saúde: Relatório Final. Coordenação Geral de Desenvolvimento de Recursos Humanos para o SUS. Brasília: Ministério da Saúde/CGDRH/SUS; 1993.

8. Ministério da Saúde (BR). 10ª Conferência Nacional de Saúde. Relatório Final. Brasília: Ministério da Saúde; 1998. Available from: http://www.conselho.saude.gov.br/biblioteca/Relatorios.htm

9. Ministério da Saúde (BR). Conselho Nacional de Saúde. Princípios e Diretrizes para NOB/RH-SUS. $2^{a}$ ed. Brasília: Ministério da Saúde; 2003.

10. Ministério da Saúde (BR). Políticas de formação e desenvolvimento para o SUS: caminhos para a educação permanente em saúde. Polos de Educação Permanente em Saúde. Brasília: Ministério da Saúde; 2004. Available from: http://bvsms.saude.gov.br/bvs/publicacoes/ politica2_vpdf.pdf

11. Ministério da Saúde (BR). Portaria no 198/GM. Em 13 de fevereiro de 2004. Institui a Política Nacional de Educação Permanente em Saúde como estratégia do Sistema Único de Saúde para a formação e o desenvolvimento de trabalhadores para o setor Saúde e de outras providências. Brasília: Ministério da Saúde;2004. Available from: https:// www.nescon.medicina.ufmg.br/biblioteca/imagem/1832.pdf

12. Ministério da Saúde (BR). Portaria no 1996/GM. Em 20 de agosto de 2007. Dispõe sobre as diretrizes para a implementação da Política Nacional de Educação Permanente em Saúde e de outras providências. Brasília: Ministério da Saúde;2007. Available from: https:// central3.to.gov.br/arquivo/341197/

13. Ganong LH. Integrative Reviews of Nursing. Rev Nurs Health [Internet]. 1987; [cited 2017 Mar 20]; 10(1):1-11. Available from: http://onlinelibrary.wiley.com/doi/10.1002/nur.4770100103/pdf. DOI: 10.1002/nur.4770100103. http://dx.doi.org/10.1002/nur.4770100103

14. Whittemore $R$, Knafl $K$. The integrative review: updated methodology. J Adv Nur [Internet]. 2005 Dez; [cited 2017 Mar 18]; 52(5):543-53. Available from: https://www.ncbi.nlm.nih.gov/pubmed/16268861. DOI: 10.1111/j.1365-2648.2005.03621.x
15. Liberati A, Altman DG, Tetzlaff J, Mulrow C, Gøtzsche PC, loannidis JP, et al. The PRISMA statement for reporting systematic reviews and meta-analyses of studies that evaluate healthcare interventions: explanation and elaboration. BMJ [Internet]. 2009 Jul; [cited 2017 Mar 20]; 339:b2700. Available from: https://www.ncbi.nlm.nih.gov/ pubmed/19622552. DOI: 10.1136/bmj.b2700

16. Rossetto M, Silva LAA. Ações de educação permanente desenvolvidas para os agentes comunitários de saúde. Cogitare Enferm [Internet]; 2010 out/dez; [cited 2017 Mar 20]; 15(4):723-9. Available from: http:// revistas.ufpr.br/cogitare/article/viewFile/20376/13546. http://dx.doi. org/10.5380/ce.v15i4.20376

17. Montanha D, Peduzzi M. Permanent education in nursing: survey to identify the necessities and the expected results based on the workers conception. Rev Esc Enferm USP [Internet]. 2010 Sep; [cited 2017 Jan 8]; 44(3):597-604. Available from: http://www.scielo.br/scielo. php?script=sci_arttext\&pid=S0080-62342010000300007\&lng=en http://dx.doi.org/10.1590/S0080-62342010000300007

18. Ricaldoni CAC, Sena RR. Permanent education: a tool to think and act in nursing work. Rev Latino Am-Enferm [Internet]. 2006 Dec; [cited 2017 Mar 20]; 14(6):837-42. Available from: http://www.scielo.br/pdf/ rlae/v14n6/v14n6a02.pdf.DOI: 10.1590/S0104-11692006000600002. http://dx.doi.org/10.1590/S0104-11692006000600002

19. Silva LAA, Franco GP, Leite MT, Pinno C, Lima VML, Saraiva N Concepções educativas que permeiam os planos regionais de educação permanente em saúde. Texto Contexto-Enferm [Internet]. $2011 \mathrm{abr} / \mathrm{jun}$ [cited 2017 Mar 20]; 20(2):340-8. Available from: http://www.scielo.br/ scielo.php?script=sci arttext\&pid=S0104-07072011000200017. http:// dx.doi.org doi.org/10.5902/217976925364

20. Silva LAA, Bonacina DM, Andrade A, Oliveira TC. Desafios na construção de um projeto de educação permanente em saúde. Rev Enferm UFSM [Internet]. 2012 set/dez; [cited 2017 Mar 20]; 2(3):496506. Available from: https://periodicos.ufsm.br/index.php/reufsm/ article/view/5364/pdf. DOI: 10.5902/217976925364. http://dx.doi. org/10.5902/217976925364

21. Queiroz DM, Silva MRF, Oliveira LC. Educação Permanente com Agentes Comunitários de Saúde: potencialidades de uma formação norteada pelo referencial da Educação Popular e Saúde. Interface (Botucatu) [Internet]. 2014; [cited 2017 Mar 20]; 18(Suppl.2):1199-210. Available from: http://www.scielo.br/scielo. php?script=sci_arttext\&pid=S1414-32832014000601199\&Ing=en\&n rm=iso. http://dx.doi.org/10.1590/1807-57622013.0303

22. Duarte MLC, Oliveira Al. Compreensão dos coordenadores de serviços de saúde sobre educação permanente. Cogitare Enferm [Internet]. 2012 jul/set; [cited 2017 Mar 20]; 17(3):506-12. Available from: http:// revistas.ufpr.br/cogitare/article/download/29292/19042. DOI: http:// dx.doi.org/10.5380/ce.v17i3.29292

23. Pereira FM, Barbosa VBA, Vernasque JRS. Continuing Education Experience for auxiliary nurses as a management strategy. REME Rev Min Enferm [Internet]. 2014 jan/mar; [cited 2017 Mar 20]; 18(1):228-242. Available from: http://www.reme.org.br/artigo/detalhes/92. http://www. dx.doi.org/10.5935/1415-2762.20140018

24. Salum NC, Prado ML. Continuing education in the development of competences in nurses. Texto Contexto-Enferm [Internet]. 2014 June; [cited 2017 Mar 20]; 23(2):301-8. Available from: http://www.scielo.br/ scielo.php?script=sci_arttext\&pid=S0104-07072014000200301\&lng =en\&nrm=iso. http://dx.doi.org/10.1590/0104-070720140021600011

25. Viana DM, Araujo RS, Vieira RM, Nogueira CM, Oliveira VC, Rennó HMS. A educação permanente em saúde na perspectiva do enfermeiro na estratégia de saúde da família. Rev Enferm Centro-Oeste Mineiro [Internet]. 2015 mai/ago; [cited 2017 Mar 20]; 5(2):1658-68. Available from: http://www.seer.ufsj.edu.br/index.php/recom/article/ view/470/868. http://dx.doi.org/10.19175/recom.v0i0.470

26. Koerich C, Erdmann AL. Meanings attributed by nursing staff about permanent education in cardiovascular institution. Rev RENE [Internet] 2016 jan/fev; [cited 2017 Mar 20]; 17(1):93-102. Available from: http:// www.revistarene.ufc.br/revista/index.php/revista/article/view/2223/ pdf_1. DOI: 10.15253/2175-6783.2016000100013 
27. Yamamoto TS, Machado MTC, Silva Júnior AG. Educação permanente em saúde como prática avaliativa amistosa à integralidade em teresópolis, Rio de Janeiro. Trab Educ Saúde [Internet]. 2015 jan/set; [cited 2017 Mar 20]; 13(3):617-38. Available from: http://www.scielo.br/ scielo.php?script=sci_arttext\&pid=S1981-77462015000300617\&lng=e n\&nrm=iso. http://dx.doi.org/10.1590/1981-7746-sip00058

28. Machado JFFP, De Carli AD, Kodjaoglanian VL, Santos MLM. Educação Permanente no cotidiano da Atenção Básica no Mato Grosso do Sul. Saúde Debate [Internet]. 2015 jan/mar; [cited 2017 mar 20]; 39(104):102-13. Available from: http://www.scielo.br/scielo. php?script=sci_arttext\&pid=S0103-11042015000100102\&lng=en\&nr m=iso. http://dx.doi.org/10.1590/0103-110420151040223

29. Coriolano MWL, Lima MM, Queiroga BAM, Ruiz-Moreno L, Lima LS. Continuing education with community health agents: a proposal for care of asthmatic children. Trab Educ Saúde [Internet]. 2012 Mar/June; [cited 2017 Mar 20]; 10(1):37-59. Available from: http://www.scielo.br/scielo. php?script=sci_arttext\&pid=S1981-77462012000100003\&lng=en\&nr $\mathrm{m}=$ iso. http://dx.doi.org/10.1590/S1981-77462012000100003

30. Slomp H, Feuerwerker LCM, Merhy EE. Histórias de vida, homeopatia e educação permanente: construindo o cuidado compartilhado. Ciência \& Saúde Coletiva, 20(6):1795-1803, 2015. Avaible from: http://www. redalyc.org/pdf/630/63038653015.pdf. http://dx.doi.org/10.1590/141381232015206.13672014

31. Paschoal AS, Mantovani MF, Méier MJ. Percepção da educação permanente, continuada e em serviço para enfermeiros de um hospital de ensino. Rev Esc Enferm USP [Internet]. 2007 set; [cited 2017 Mar 20]; 41(3):478-84. Available from: http://www.scielo.br/ scielo.php?script=sci_arttext\&pid=S0080-62342007000300019\&lng= en\&nrm=iso. DOI: 10.1590/S0080-62342007000300019. http://dx.doi. org/10.1590/S0080-62342007000300019

32. Pinto EEP, Araújo MD, Matumoto S, Capozzolo AA, Cardoso MRL, Mishima SM. Desdobramentos da educação permanente em saúde no município de Vitória, Espírito Santo. Trab Educ Saúde [Internet]. 2010 mar/jun; [cited 2017 Mar 20]; 8(1):77-96. Available from: http://www.scielo.br/scielo.php?script=sci arttext\&pid=S1981$77462010000100005 \&$ Ing=en\&nrm=iso. http://dx.doi.org/10.1590/ S198177462010000100005

33. Nicoletto SCS, Mendonca FF, Bueno VLRC, Brevilheri ECL, Almeida DCS, Rezende LG, et al. Centers for permanent healthcare education: an analysis on the experience of social players in the north of the state of Paraná. Interface (Botucatu) [Internet]. 2009 Jul/Sep; [cited 2017 Mar 20]; 13(30):209-19. Available from: http://www.scielo.br/scielo. php?script=sci_arttext\&pid=S1414-32832009000300017\&lng=en\&nr m=iso. http://dx.doi.org/10.1590/S1414-32832009000300017

34. Carvalho BG, Turini B, Nunes EFPA, Bandeira IF, Barbosa PFA, Takao TA. Percepção dos médicos sobre o curso facilitadores de Educação Permanente em Saúde. Rev Bras Educ Med [Internet]. 2011 jan/mar; [cited 2017 Mar 20]; 35(1):132-41. Available from: http://www.scielo.br/ scielo.php?script=sci_arttext\&pid=S0100-55022011000100018\&lng=e n\&nrm=iso. http://dx.doi.org/10.1590/S0100-55022011000100018

35. Cardoso MC. "Rodas de educação permanente" na atenção básica de saúde: analisando contribuições. Saude Soc [Internet]. 2012 maio; [cited 2017 Mar 20]; 21(Suppl.1):18-28. Available from: http://www.scielo.br/ scielo.php?script=sci arttext\&pid=S0104-12902012000500002\&lng= en\&nrm=iso. $h$ ttp://dx.doi.org/10.1590/S0104-12902012000500002

36. Tesser CD, Garcia AV, Vendruscolo C, Argenta CE. Estratégia saúde da família e análise da realidade social: subsídios para políticas de promoção da saúde e educação permanente. Ciênc Saúde Coletiva [Internet]. 2011 nov; [cited 2017 Mar 20]; 16(11):4295-306. Available from: http://www.scielo.br/scielo.php?script=sci_arttext\&pid=S1413$81232011001200002 \&$ Ing =en. http://dx.doi.org/10.1590/S141381232011001200002

37. Fortuna CM, Franceschini TRC, Mishima SM, Matumoto S, Pereira MJB Movements of permanent health education triggered by the training of facilitators. Rev Latino-Am Enferm [Internet]. $2011 \mathrm{Mar} / \mathrm{Apr}$; [cited 2017 Mar 20]; 19(2):411-20. Available from: http://www.scielo.br/scielo. php?script=sci_arttext\&pid=S0104-11692011000200025\&lng=en\&nrm =iso. http://dx.doi.org/10.1590/S0104- 11692011000200025
38. Silva JAM, Peduzzi M. Educação no Trabalho na Atenção Primária à Saúde: interfaces entre a educação permanente em saúde e o agir comunicativo. Saude Soc [Internet]. 2011 out/dez; [cited 2017 Mar 20]; 20(4):1018-32. Available from: http://www.scielo.br/scielo. php? script=sci_arttext\&pid=S0104-12902011000400018\&lng=en http://dx.doi.org/10.1590/S0104-12902011000400018

39. Gonçalves LC, Cortez EA, Cavalcanti ACD. Permanent Education in relation to Family Health Strategy: a descriptive-exploratory study. Online Braz J Nurs [Internet]. 2013 Oct; [cited 2017 Mar 20]; 12:593-95. Available from: http://www.objnursing.uff.br/index.php/nursing/article/ view/4528. http://dx.doi.org/10.5935/1676-4285.20134528

40. Silva CT, Terra MG, Mostadeiro SCTS, Ribeiro DR, Lavich CR, Xavier MS. Nucleus of permanente education in nursing: perspectives in a teaching hospital. Rev Pesq Cuid Fundam [Internet]. 2013 Apr; [cited 2017 Mar 20]; 5(3):114-21. ISSN 2175-5361. Available from: http://www. seer.unirio.br/index.php/cuidadofundamental/article/view/2044/pdf_825

41. Feliciano KVO, Kovacs MH, Costa IER, Oliveira MG, Araújo AMS Avaliação continuada da educação permanente na atenção à criança na estratégia saúde da família. Rev Bras Saude Mater Infant. [Internet]. 2008 jan/mar; [cited 2017 Mar 20]; 8(1):45-53. Available from: http://www.scielo.br/scielo.php?script=sci_arttext\&pid=S151938292008000100006\&lng=en\&nrm=iso. http://dx.doi.org/10.1590/ S1519-38292008000100006

42. Cunha AZS, Rezende MS, Weigelt LD, Krug SBF, Feil AI. Implicações da educação permanente no processo de trabalho em saúde. Espaç Saúde (Internet). 2014 out/dez; [cited 2017 Mar 20]; 15(4):64-75. Available from: http://www.uel.br/revistas/uel/index.php/espacoparasaude/ article/view/19911/pdf_48. http://dx.doi.org/10.22421/15177130.2014v15n4p64

43. MarandolaTR, Marandola CMR, Melchior Baduy R, Staevie R. Educação permanente em saúde: conhecer para compreender. Espaç Saúde [Internet]. 2009 jun; [cited 2017 Mar 20]; 10(2):53-60. Available from: http://bases.bireme.br/cgi-bin/wxislind.exe/iah/online/?IsisScript=iah/ iah. $x$ is\&src=google\&base=LILACS\&lang=p\&nextAction=Ink\&exprSea $\mathrm{rch}=528446$ \&indexSearch $=$ ID

44. Mishima SM, Aiub AC, Rigato AFG, Fortuna CM, Matumoto S, Ogata MN et al. Managers' perspective on continuous health education in a region of São Paulo State. Rev Esc Enferm. USP [Internet]. 2015 July/Aug; [cited 2017 Mar 20]; 49(4):0665-73. Available from: http://www.scielo.br/scielo. php?script=sci_arttext\&pid=S0080-62342015000400665\&lng=en\&nrm =iso\&tlng=en. http://dx.doi.org/10.1590/S0080-623420150000400018

45. Silva AM, Peduzzi M. Caracterização das atividades educativas de trabalhadores de enfermagem na ótica da educação permanente. Rev Eletr Enferm [Internet]. 2009 set; [cited 2017 Mar 20]; 11(3):518-26. Available from: https://www.fen.ufg.br/fen_revista/v11/n3/pdf/v11n3a08. pdf

46. Peduzzi M, Del Guerra DA, Braga CP, Lucena FS, Silva JAM. Educational activities for primary healthcare workers: "educação permanente em saúde" and continuing education concepts in the dayto-day routine of primary healthcare units in São Paulo. Interface (Botucatu) [Internet]. 2009 Jul/Sep; [cited 2017 Mar 18]; 13(30):121-34. Available from: http://www.scielo.br/scielo.php?script=sci_arttext\&pid=S1414$32832009000300011 \& \mathrm{lng}=$ en. http://dx.doi.org/10.1590/S1414 32832009000300011

47. Lavado MM, Benito GAV, Bitdinger C, Soares CLS, Silva TAV. Avaliação do processo de trabalho médico no programa saúde da família: uma ferramenta para educação permanente. ACM Arq Catarin Med [Internet]. 2007; [cited 2017 Mar 20]; 36(2):75-81. Available from: http://www.acm. org.br/revista/pdf/artigos/485.pdf

48. Silva LAA, Leite MT, Hildebrandt LM, Pinno C. Educação permanente em saúde na ótica de membros das comissões de integração ensinoserviço. Rev Enferm UFSM [Internet]. 2014 maio/ago; 3(2):296-306.

49. Rocha NHN, Bevilacqua PD, Barletto M. Metodologias participativas e educação permanente na formação de agentes comunitários/as de saúde. Trab Educ Saúde [Internet]. 2015; [cited 2017 Mar 20]; 13(3):597615. Available from: http://www.scielo.br/scielo.php?pid=S1981 77462015000300597\&script=sci_abstract\&tlng=es. http://dx.doi. org/10.1590/1981-7746-sip00056 
50. Santos AM, Nóbrega, IKS, Assis MMA, Jesus SR, Kochergin CN, Bispo Júnior JP, et al. Desafios à gestão do trabalho e educação permanente em saúde para a produção do cuidado na estratégia saúde da família. Rev APS [Internet]. 2015 jan/mar [cited 2017 Mar 20]; 18(1):39-49. Available from: https://aps.ufjf.emnuvens.com.br/aps/ article/view/2320/857

51. Sade PMC, Peres AM. Development of nursing management competencies: guidelines for continuous education services. Rev Esc Enferm USP [Internet]. 2015 Dec; [cited 2017 Mar 20]; 49(6):988994. Available from: http://www.scielo.br/scielo.php?script=sci arttext\&pid=S0080-62342015000600988\&lng=en\&nrm=iso. http:// dx.doi.org/10.1590/S0080-63420150000600016

52. Ricardi LM, Sousa MF. Educação permanente em alimentação e nutrição na Estratégia Saúde da Família: encontros e desencontros em municípios brasileiros de grande porte. Ciênc Saúde Coletiva [Internet]. 2015 jan; [cited 2017 Mar 20]; 20(1):209-18. Available from: http://www.scielo.br/scielo.php?script=sci_arttext\&pid=S1413$81232015000100209 \&$ Ing=en\&nrm=iso. $h t t p: / / d x . d o i . o r g / 10.1590 / 1413$ 81232014201.20812013

53. Leite MTS, Sena RR, Vieira MA, Mendonça JMG, Dias OV, Santos MIP, et al. Perspectivas de educação permanente em saúde no norte de Minas Gerais. REME Rev Min Enferm [Internet]. 2012 out/ dez; [cited 2017 Mar 20]; 16(4):594-600. Available from: http://www. reme.org.br/artigo/detalhes/566. http://www.dx.doi.org/S141527622012000400016

54. Silva KL, Ribeiro HCTC, Pereira LDP, Martins BRM, Viana JA, Belga SMMF. Plano diretor de atenção primária como estratégia de educação permanente: perspectiva dos facilitadores. Rev RENE [Internet]. 2012 jul/ago [cited 2017 Mar 20]; 13(3):552-61. Available from: http://www. periodicos.ufc.br/rene/article/view/3977/3140

55. Lima SAV, Albuquerque PC, Wenceslau, LD. Educação permanente em saúde segundo os profissionais da gestão de Recife, Pernambuco.Trab Educ Saúde [Internet]. 2014 mai/ago; [cited 2017 Mar 20]; 12(2):42541. Available from: http://www.scielo.br/scielo.php?script=sci_artt ext\&pid=S1981-77462014000200012. http://dx.doi.org/10.1590/ S198177462014000200012

56. Signor E, Silva LAA, Gomes IEM, Ribeiro RV, Kessler M, Weiller TH, et al. Educação permanente em saúde: desafios para a gestão em saúde pública. Rev Enferm UFSM [Internet]. 2015 jan/mar [cited 2017 Mar 20]; 5(1):1-11. Available from: https://periodicos.ufsm.br/reufsm/ article/view/14766. http://dx.doi.org/10.5902/2179769214766

57. Mendonça FF, Nunes EFPA. Necessidades e dificuldades de tutores e facilitadores para implementar a política de educação permanente em saúde em um município de grande porteno estado do Paraná,
Brasil. Interface (Botucatu) [Internet]. 2011 jul/set; [cited 2017 Mar 20]; 15(38):871-82. Available from: http://www.scielo.br/scielo. php?script=sci_arttext\&pid=S1414-32832011000300020\&Ing=en\&n rm=iso. http://dx.doi.org/10.1590/S1414-32832011000300020

58. Paim CC, llha S, Backes DS. Permanent education in health in an intensive care unit: the perception of the nurses. Rev Pesqui Cuid Fundam [Internet].2015 Jan [cited 2017 Mar 20]; 7(1):2001-10. Available from: http://www.seer.unirio.br/index.php/cuidadofundamental/article/ view/3586. DOI: http://dx.doi.org/10.9789/21755361.2015.v7i1.20012010

59. Monteiro PHN, Batista KBC, Pupo LR, Barboza LR, Escuder MML. Avaliação pedagógica nos cursos do polo de educação permanente da grande: fragilidades e desafios. Mundo Saúde. 2007;31(3):336-45.

60. Ministério da Saúde (BR). Secretaria-Executiva. Subsecretaria de Assuntos Administrativos. Educação Permanente em Saúde: um movimento instituinte de novas práticas no Ministério da Saúde. Brasília: Ministério da Saúde;2014. Available from: http://bvsms.saude. gov.br/bvs/publicacoes/educacao_permanente_saude_movimento_ instituinte.pdf

61. Moraes KG, Dytz JLG. Política de educação permanente em saúde: análise de sua implementação. ABCS Health Sci [Internet]. 2015; [cited 2017 Mar 18]; 40(3):263-9. Available from: https://www.portalnepas.org. br/abcshs/article/viewFile/806/701. http://dx.doi.org/10.7322/abcshs. v40i3.806. http://files.bvs.br/upload/S/2318-4965/2016/v40n3/a5357. pdf

62. Lemos CL. Educação Permanente em Saúde no Brasil: educação ou gerenciamento permanente? Ciênc Saúde Coletiva [Internet] 2016 mar; [cited 2017 mar 18]; 21(3):913-22. Available from: http://www.scielo.br/scielo.php?script=sci_arttext\&pid=S1413$81232016000300913 \&$ Ing=en. http://dx.doi.org/10.1590/141381232015213.08182015

63. Barbosa VBA, Ferreira MLSM, Barbosa PMK. Continuing health educating: a strategy for the training of community health agents. Rev Gaúcha Enferm [Internet]. 2012 Mar; [cited 2017 Mar 18]; 33(1):5663. Available from: http://www.scielo.br/scielo.php?script=sci arttext\&pid=S1983-14472012000100008\&lng=en. http://dx.doi. org/10.1590/S1983-14472012000100008

64. Nicoletto SCS, Bueno VLRC, Nunes EFPA, Cordoni Júnior L, González $A D$, Mendonça FF, et al. Desafios na implantação, desenvolvimento e sustentabilidade da Política de Educação Permanente em Saúde no Paraná, Brasil. Saude Soc [Internet]. 2013 out/dez [cited 2017 mar 20]; 22(4):1094-105. Available from: http://www.scielo.br/scielo. php?script=sci_arttext\&pid=S0104-12902013000400012\&Ing=en . http://dx.doi.org/10.1590/S0104-12902013000400012.FREME 